\title{
PENERAPAN METODE DISKUSI UNTUK MENINGKATKAN HASIL BELAJAR SISWA PADA BIDANG STUDI IPS SEJARAH DI SEKOLAH DASAR
}

\author{
${ }^{1}$ Acep Roni Hamdani, M.Pd \\ ${ }^{2}$ Rijal Subelli, S.Pd \\ ${ }^{1}$ Mahasiswa Pascasarjana UPI \\ ${ }^{2}$ Mahasiswa STKIP Subang \\ 1acepronihamdani@rocketmail.com \\ 2rizalsubelli@gmail.com
}

\begin{abstract}
This study aims to: (1) find out whether the discussion method can improve student learning outcomes in the field of study Social Science class V SDN Sukabakti Subang Regency; (2) to describe the steps of applying the method of discussion in improving student learning outcomes in the field of Social Science study of students of grade V SDN Sukabakti Subang Regency. This type of research is Classroom Action Research (PTK), using Suaharsimi Arikunto design. Subjects in this study are the students of grade V SDN Sukabakti Subang Regency which amounted to 27 students. Technique of collecting test data, observation observation, field note, and dokuentasi.tes are used to collect student's cognitive learning data, while observation sheet is used to obtain learning result of afectic aspect, psychomotor, and teacher activity in learning process of Social Science using discussion method. Quantitative decryption analysis techniques to calculate the data of cognitive learning outcomes and qualitative dekristif analysis to mengisisisis data observation results. The results showed that the application of the method of discussion in the field of Social Science study of students in grade V SDN Sukabakti Subang Regency. Based on test results obtained by students at each end of the cycle showed an increase in Social Science learning outcomes. Percentage of completeness on pratindakan by $19 \%$, cycle I by $63 \%$ and cycle II by $93 \%$. The process shows that the quality of the learning process becomes increasing, the students look more active, critical, and communicative and susana learning more fun and conducive. In the application of the method of discussion the teacher needs to pay attention to the following matters: (1) to examine the preparations that are deemed to affect the smoothness of the discussion, (2) provide guidance before discussion, (3) implement the rules of discussion according to the rules of the game, 4) Giving equal opportunity to every discussion participant to issue his ideas or ideas, (5) controlling the issue to the subject being discussed, (6) creating a relaxed, fun but controlled learning atmosphere.
\end{abstract}

Keywords: Social Science Learning Results, Discussion Method 
ABSTRAK

Penelitian ini bertujuan untuk: (1) mengetahui apakah metode diskusi dapat meningkatkan hasil belajar siswa pada bidang studi IPS kelas V SDN Sukabakti Kabupaten Subang; (2)mendekripsikan langkah-langkah penerapan metode diskusi dalam meningkatkan hasil belajar siswa pada bidang studi IPS siswa kelas V SDN Sukabakti Kabupaten Subang. Jenis penelitian ini adalah Peneltian Tindakan Kelas (PTK), menggunakan desain Suaharsimi Arikunto. Subjek dalam penelitian ini adalah siswa kelas V SDN Sukabakti Kabupaten Subang yang berjumlah 27 siswa. Teknik pengumpulan data tes,lembear observasi,catatan lapangan,dan dokuentasi.tes digunakan untuk mengumpulkan datahasil belajar kognitif siswa, sedangkan lembar observasi di gunakan untuk memperoleh hasil belajar aspek afektik, psikomotor, serta aktifitas guru dalam proses pembelajaran IPS menggunakan metode diskusi. Teknik analisis dekripsifkuantitatif untuk menghitung data hasil belajar kognitif dan analisi dekristif kualitatif untuk mengenalisis data hasil observasi. Hasil penelitian menunjukan bahwa penerapan metode diskusi pada bidang studi IPS siswa kelas V SDN Sukabakti Kabupaten Subang. Berdasarkan hasil tes yang diperoleh siswa pada setiap akhir siklus menunjukan peningkatan hasil belajar IPS . presentase ketuntasan pada pratindakan sebesar $19 \%$, siklus I sebesar $63 \%$ dan siklus II sebesar $93 \%$. Secara proses menunjukan bahwa kualitas proses pembelajaran menjadi meningkat, terlihat siswa lebih aktif, kritis, dan komunikatif serta susana pembelajaran lebih menyenangkan dan kondusif. Dalam penerapan metode diskusi guru perlu memperhatikan halhal sebagai berikut:(1) memeriksa persiapan yang dianggap dapat mempengaruhi kelancaran diskusi;(2)memberikan pengarahan sebelum dilaksanakan diskusi;(3) melaksanakan aturan diskusi sesuai aturan main yang telah ditetapkan;(4)memberikan kesempatan yang sama kepada setiap pesert diskusi untuk mengeluarkan gagasan atau ideidenya;(5)mengendalikan persoalan kepada pokok persoalan yang sedang dibahas;(6) menciptakan suasan pembelajaran yang santai, menyenangkan namun terkendali.

Kata kunci : Hasil Belajar IPS, Metode Diskusi

\section{A. PENDAHULUAN}

Dalam upaya menghadapi tantangan di era globalisasi yang semakin kompetitif, dipandang perlu adanya upaya untuk menyiapkan kualitas sumber daya manusia yang mempunyai daya saing unggul dalam menghadapi semua bentuk tantangan masa yang akan datang. Untuk memenuhi semua itu, maka upaya menciptakan rekayasa sosial yang berkaitan dengan peningkatan mutu pendidikan merupakan relevansi yang logis. Disadari ataupun tidak pendidikan memiliki 
peran yang strategis membentuk pemahaman dasar dalam menentukan arah rekayasa tersebut. Itu sesuai dengan pernyataan John Dewey (Sagala, 2003:3) bahwa: Pendidikan merupakan proses pembentukan kemampuan dasar yang fundamental, baik menyangkut daya pikir atau daya intlektual, maupun daya emosional atau perasaan yang diarahkan kepada tabiat manusia dan kepada sesamanya.

Pemahaman dasar merupakan bagian kecil dari fungsi pendidikan dalam upaya mewujudkan cita-cita bangsa dan membangun watak, serta arah bangsa kedepan. Semua itu sesuai dengan fungsi pendidikan yang termuat dalam UU No 20 tahun 2003 tentang sistem Pendidikan Nasional, bahwa Pendidikan Nasional berfungsi mengembangkan kemampuan dan membentuk watak serta peradaban bangsa yang bermartabat dalam rangka mencerdaskan kehidupan bangsa, bertujuan untuk berkembangnya potensi peserta didik agar menjadi
Manusia yang beriman dan bertakwa kepada Tuhan Yang Maha Esa, berakhlak mulia, sehat, berilmu, cakap, kreatif, mandiri, dan menjadi warga negara yang demokratis serta bertanggung jawab.

Proses pendidikan yang berlangsung saat ini semua akan terwujud sesuai harapan apabila proses pembelajaran efektif, pada dasarnya itu berimplikasi pada kompetensi seorang pendidik. Karena keberhasilan suatu pendidikan tidak dapat dilepaskan dari peran pendidik. Oleh sebab itu, pendidik menjadi komponen yang penting dalam sebuah sistem pendidikan. Kualitas kinerja profesional seorang pendidik tidak hanya sebatas menguasai bahan ajar, menerapkan metode pembelajaran yang baik, dan tidak pula seorang pendidik hanya memiliki tugas melaksanakan administrasi, pengelolaan, pengembangan, pengawasan, dan pelayanan teknis untuk menunjang proses pendidikan pada satuan pendidikan. Melainkan dituntut memiliki mutu pembelajaran dan penguasaan 
kelas yang kondusif serta terstruktur dengan baik.

Dalam proses penguasaan kelas seharusnya, seorang pendidik dapat menguasai teknikteknik dalam menciptakan suasana belajar yang baik. Tahap yang cukup fundamental dan menyentuh kondisi psikologi peserta didik yakni untuk memberikan motivasi kepada peserta didik. Tetapi kenyataan yang terjadi di lapangan pendidik masih menggunakan pembelajaran yang bersifat konvensional, akibatnya peserta didik kurang memahami materi yang di ajarkan. Dengan demikian pendidik harus memberikan motivasi kepada peserta didik. Sagala (2003:115) yang mengemukakan bahwa: Manfaat motivasi untuk peserta didik adalah (1) membangkitkan, meningkatakan, dan memelihara semangat belajar sampai berhasil; (2) mengobarkan semangat belajar peserta didik; (3) meningkatkan dan menyadarkan guru untuk memilih satu diantara macammacam peran yang sesuai dengan bidang studi yang diajarkannya; dan (4) memberi peluang guru untuk "unjuk kerja" rekayasa pedagogis tugas guru adalah membuat semua peserta didik sampai berhasil. Dengan semua itu perserta didik dan pendidik dapat memainkan peran sehingga pada akhirnya mencapai hasil belajar yang sesuai dengan apa yang telah ditentukan.

Proses pembelajaran tidak selalu efektif dan hasil belajar mengajar tidak selalu optimal, karena ada sejumlah hambatan. Karena itu, pendidik dalam menyampaikan materi pelajaran tersebut disesuaikan dengan kebutuhan mereka akan pelajaran tersebut. Ada petunjuk umum untuk mengatasi kesulitan belajar menurut Rusyan (Sagala, 2003:59) yaitu: (1) menetapkan target dan tujuan belajar yang jelas; (2) menghindari saran dan kritik yang negatif; (3) menciptakan situasi belajar yang sehat dan kompetitif; (4) menyelenggarakan ramedial program; dan (5) memberi kesempatan agar peserta didik mempeoleh pengalaman sukses.

Jikalau pendidik dapat mengatasi kesulitan belajar, maka dengan mudah pendidik dapat 
menetukan keberhasilan suatu pembelajaran yakni ditunjukan dengan adanya penguasaan materi pembelajaran oleh peserta didik dan perubahan tingkah laku, jika hal itu belum dikuasai oleh peserta didik, maka pendidik melalui refleksi perlu melakukan pembelajaran untuk mengidentifikasi masalah. Baik dari menemukan masalah, menemukan penyebab kegagalan dan merumuskan masalah serta memperbaikinya. Menurut Susanto (2014:6) IImu pegetahuan sosial (IPS) merupakan integrasi dari berbagai cabang ilmu-ilmu sosial di antaranya yaitu; sosiologi, sejarah, geografi, ekonomi, politik, hukum, dan budaya. IImu pengetahuan sosial di rumuskan atas dasar realitas dan fenomena sosial yang mewujudkan satu pendekatan interdisipliner dari aspek dan cabang ilmu-ilmu sisoal di atas. Sesuai dengan peraturan Permendiknas RI No 22 tahun 2006 bahwa ,Bidang studi IPS dalam pendidikan di Indonesia di berikan untuk peserta didik mulai jenjang SD/MI, SMP/MTS, SMA/MA serta Sekolah Menengah
Kejuruan

(SMK).

IImu pengetahuan sosial (IPS) mengkaji seperangkat peristiwa, fakta ,konsep, dan generalisasi yang berkaitan dengan ilmu sosial. (Sapriya 2009: 193-194).

Menurut Sapriya (2009:43) bahwa pendidikan IPS untuk SD/MI yakni: Materi pelajaran dibagi atas dua bagian yakni materi sejarah dan materi pengetahuan sosial. materi pengetahuan sosial meliputi lingkungan sosial, geografi, ekonomi dan politik. Sedangkangkan cagkupan materi sejarah meliputi sejarah lokal dan nasional. Tujuannya adalah untuk mengembangkan penegtahuan peserta didik dan keterampilan dasar yang akan di gunakan dalam kehidupan serta meningkatkan rasa nasionalisme dari peristiwa masa lalu hingga masa sekarang agar peserta didik memiliki rasa kebanggaan dan cinta tanah air.

Bidang studi sejarah merupakan cabang dari ilmu pengetahuan Sosoal yang menelaah tentang asal-usul dan perkembangan serta peranan masyarakat dimasa lampau 
berdasarkan metode dan metodologi tertentu, (Sapriya:208209). Bidang studi sejarah, salah satu bidang studi yang dipandang mudah oleh peserta didik, namun secara substansi penguasaan materi ini pemahamannya tidak dengan instant dapat dipahami.

Berdasarkan observasi di lapangan, pembelajaran IPS di SDN Sukabakti jauh dari harapan, karena hasil belajarnya dibawah KKM. Berdasarkan hasil observasi awal yang dilakukan di kelas $\mathrm{V}$ SDN Sukabakti, pada bidang studi IPS pada materi "Menceritakan tokoh-tokoh sejarah pada masa hindu, budha, dan Islam di Indonesia" masih terbilang rendah, bahkan dapat dikategorikan nilai hasil belajar peserta didik belum maksimal. Hal ini bisa dilihat dari nilai rata-rata ulangan harian yang masih dibawah KKM. Berdasarkan data yang diperoleh, dapat disimpulkan bahwa KKM bidang studi IPS SDN Sukabakti kelas V 70 , nilai rata-rata yang diperoleh 59,85 dengan jumlah peserta didik 27. Hanya 5 peserta didik yang mencapai KKM. Artinya hanya $18,51 \%$ peserta didik yang dapat di katakan sudah mencapai tingkat penguasaaan materi sesuai KKM.

Hal itu disebabkan karena perhatian dan aktifitas peserta didik untuk belajar sangat kurang. Peserta didik mengalami kesulitan untuk mencapai hasil belajar yang maksimal. Salah satu penyebabnya adalah pengajaran yang digunakan banyak verbalisme atau ceramah yang malah tidak menarik perhatian peserta didik, pendidik jarang melibatkan peserta didik untuk beraktivitas dalam proses belajar mengajar. Maka dari itu pengajaran harus divariasi dengan metode-metode lain. Seperti metode Demonstrasi, Eksperimen, Diskusi, Pembelajaran Berbasis Masalah, Inkuiri, Penggunaan Alat Peraga dan lain-lain.

Banyak metode pembelajaran yang bisa di terapkan untuk pembelajaran pada bidang studi IPS di Sekolah Dasar. Namun metode tersebut harus disesuaikan dengan bahan ajar yang akan disampaikan dan dikondisikan dengan keadaan peserta didik serta fasilitas sekolah. Maka dari itu Pendidik 
harus terampil dalam mensiasati metode pembelajaran yang akan di terapkan, karena pada kenyataanya di lapangan, banyak sekolah yang belum memilik fasilitas, berupa alat peraga.

Dalam penilitian ini peneliti mengambil Metode diskusi untuk meningkatkan hasil belajar siswa karna menurut Killen (Sanjaya:154) Metode diskusi adalah metode pembelajaran yang menghadapkan peserta didik pada suatu permasalahan. Tujuan utama metode ini adalah untuk memecahakan suatu masah, menjawab pertanyaan, menambah dan memahami pengetahuan siswa, tukar menukar informasi, serta untuk membuat keputusan bersama. Oleh karena itu diskusi bukan debat. Berdasrkan penemuan masalah dilapagan, khususnya di SDN Sukabakti, perlunya penerapan Metode pembelajaran untuk meningkatkan hasil belajar peserta didik diantaranya dengan menggunakan Metode diskusi.

Semua itu semakin dipertegas oleh hasil penelitian Nana koniman (2013:120) mengenai Penerapan Metode diskusi pada bidang studi IPS di SDN Padamukti Kecamatan Binong Kabupaten Cianjur. Penelitian tersebut menghasilkan bahwa dengan Metode diskusi dapat meningkatkan hasil belajar peserta didik yang lebih baik. Dan aktifitas siswa dalam pembelajaran IPS pada materi perkembangan teknologi lebih meningkat, karena melalui metode diskusi peserta didik mampu menambah dan memahami pengetahuan, mampu berfikir kritis, bekerjasama, aktif, menghargai pendapat orang lain serta mampu membuat keputusan bersama.

Atas dasar pemikiran tersebut peneliti beranggapan bahwa perlunya pembelajaran dengan menggunakan Metode diskusi untuk meningkatkan hasil belajar siswa dalam pembelajaran IPS terutama pada materi Menceritakan tokoh-tokoh sejarah pada masa Hindu, Budha, dan Islam di Indonesia. Dengan menerapkan metode diskusi ini di harapkan dapat meningkatkan hasil belajar peserta didik yang lebih baik. 


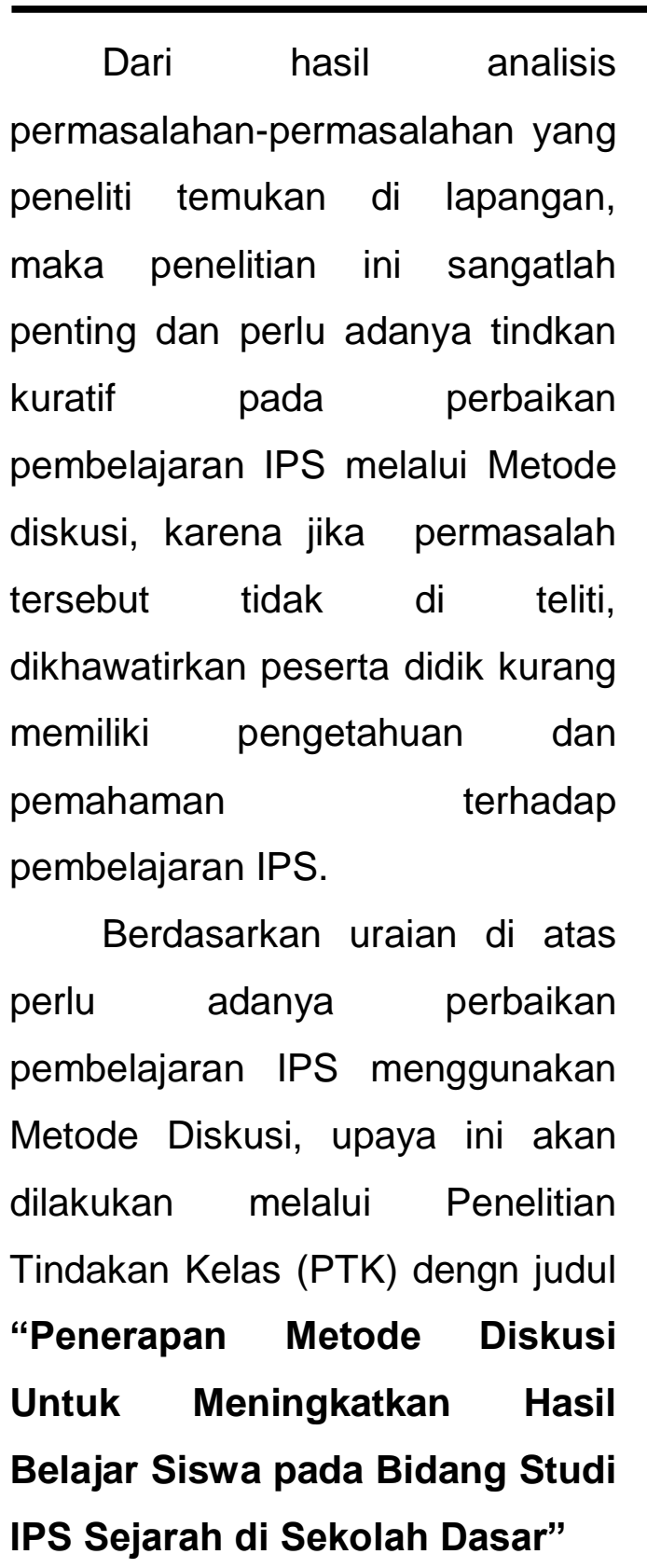

\section{B. LANDASAN TEORI}

\section{Metode Diskusi}

a. Pengertian Metode Diskusi

Dalam pendidikan kata metode digunakan untuk menunjukan serangkaian kegiatan guru yang terarah yang menyebabkan siswa belajar, metode adalah cara yang
digunakan mengimplementsikan rencara yang sudah di susun dalam kegiatan nyata agar tujuan yang tealah di sususn tercapai secara optimal. (Wina sanjaya, 2006:147). Metode juga dapat pula di anggap sebagai cara atau prosedur yang keberhasilannya adalah di dalam belajar atau sebagai alat yang menjadikan mengajar menjadi efektif.

Metode diskusi telah lama dikenal dalam pengajaran IPS/SS dan ilmu-ilmu sosial. Diskusi adalah suatu tugas yang benarbenar memerlukan keahlian, oleh sebab itu apa yang di sebut metode diskusi belum di terapkan dengan baik dan persiapan yang sunggh-sungguh baik dari pihak guru, sekolah, maupun siswa. Mengapa demikian. Oleh karena itu diskusi yang sebenarnya adalah salah satu diantara teknik yang paling mujarab sekaligus paling sulit, oleh sebab itu menggunakan sejak dini sebisa siswa amatlah baik, terutama kegunaanya dalam pembelajaran IPS/SS. Oleh karena itu diskusi yang digunakan dengan 
benar merupakan salah satu metode yang efektif dan ketepatgunaanya akan sangat berguna dalam pembelajaran IPS/SS. Abdul azis wahab (2012:100).

Berbicara mengenai metode pembelajaran, memang cukup menarik untuk dipahami, karena setiap kegiatannya menghadapkan permasalahan kepada peserta didik. Pada dasarya menurut Killen (Sanjaya, 2006:154) Metode diskusi adalah metode pembelajaran yang menghadapkan siswa pada suatu permasalahan. Tujuan utama metode ini adalah untuk memecahakan suatu masah, menjawab pertanyaan, menambah dan memahami pengetahuan siswa, tukar menukar informasi, serta untuk membuat keputusan bersama.

Adapun metode diskusi menurut Djauzak ahmad (Sopidah, 2011:12), dapat didefinisikan sebagai suatu aktifitas dari sekelompok siswa, berbicara tentang saling bertukar inforamasi maupun pendapat tentang sebuah tofik atau masalah dalam rangka mencari jawaban /penyelesaian problrm dari segala segi dan kemungkinan yang ada, adapun metode diskusi menurut pendapat Ishak abdulhak (sopidah, 2011:12) sesuatu cara yang di gunakan pada proses pembelajaran melalui kerja kelompok untuk membahas dan memecahkan permasalahan yang ditugaskan, hingga dapat melahirkan suatu kesepakatan bersama, lebih tegas menurut Winna sanjaya (2008:152) mengemukakan bahwa metode diskusi adalah metode pembelajaran yang mengharapkan siswa untuk memecahkan masalah , menambah pengetahuan, dan menjwab pertanyaan.

Beda halnya menurut Djamarah (2010:87) mengemukakan bahwa: Metode diskusi adalah cara penyajian pelajaran, dimana siswa-siswa dihadapkan kepada suatu masalah yang bisa berupa pernyataan atau pertanyaan yang bersift problematis untuk di bahas dan di pecahkan bersama, didalamnya terjadi interaksi antar dua individu atau lebih individu yang terlibat, saling tukar menukar pengalaman, 
informasi, memecahkan masalah, dapat terjadi juga semuanya aktif, tidak ada yang pasif sebagai pendengar saja.

Tidak hanya individu-individu yang terlibat tukar menukar pengalaman ataupun informasi namun, Metode diskusi adalah percakapan ilmiah yng berisikan pertukaran pendapat, pemunculn ide-ide serta pengujian pendapat yang dilakukan oleh beberapa orang yang tergabung dalam kelompok itu untuk mencari kebenaran.

Hamdayana (20014:131).

Menurut Sagala (2014:208) Metode diskusi ialah percakapan ilmiah yang responsif berisikan pertukaran pendapat yang dijalin dengan pertanyaan-pertanyaan problematis pemunculan ide-ide dan pengujian ide-ide ataupun pendapat dilakukan oeh beberapa orang yang tergabung dalam kelompok itu yang diarahkan untuk memperoleh

pemecahan masalahnya dan untuk mencari kebenaran.

Adapun lebih jelasnya disampaikan oleh Syaiful Bahri Djamarah dan Aswan Zain (hamdayana ,2014:131) yang mengemukakan bahwa metode diskusi adalah cara penyajan pelajaran, dimana siwa-siswa dihadapkan kepada suatu masalah, yang bisa berupa pernyataan atau pertanyaan yang bersifat problemetis untuk dibahas dan di pecahkan bersama.

Dari pendapat para ahli di atas, maka metode diskusi merupakasan salah satu metode yang dapat di gunakan dalam semua proses pembelajaran termasuk dalam pembelajaran ilmu pengetehuan sosial (IPS) pada materi sejarah tentang manceritakan tokoh-tokoh sejarah pada masa hindu,budha dan Islam di Indonesia. Sehingga peserta didik dapat mengatahuai kejadian masa lampau melalaui bukti yang absah.

\section{b. Manfaat Metode Diskusi}

Manfaat diskusi antara lain menurut sagala (2014:208) adalah sebagai berikuat:

1) Peserta didik memperoleh kesempatan untuk berfikir

2) Peserta didik mendapat pelatihan mengeluarkan 

pendaapat, sikap dan aspirasinya secara bebas
3) Peserta didik belajar bersikap toleran terhadap teman- temannya
4) Diskusi dapat menumbuhkan partisipasi aktif dikalangan peserta didik
5) Diskusi dapat mengembangkan sikap demokratif, dapat menghargai pendapat orang lain dan;
6) Dengan diskusi, pelajaran menjadi relevan dengan kebutuhan masyasrakat.

\section{c. Kelebihan Metode Diskusi}

Baik metode, model, dan pendekatan yang digunakan ataupun tidak dalam proses pembelajaran berlangsung, semua itu memiliki keunggulan dan kelemahan tersendiri. Disadari tidaknya proses implementasi dari metode, model ataupun pendekatan tidak semua dapat dipergunakan pada aspek dan bahan materi ajar.

Dalam hal ini metode diskusi, satu dari sekian banyak metode yang diambil oleh peneliti untuk digunakan pada bidang studi IImu pengetahuan sosial lebih khusus

$\begin{array}{lrr}\text { dalam bahan ajar sejarah } \\ \text { mempunyai } & \text { keunggulan } & \text { dan } \\ \text { kekurangan } & \text { dalam } & \text { proses } \\ \text { implementasi } & \text { pada } & \text { proses }\end{array}$
pembelajaran di kelas, karena yang dihadapi peserta didik dengan tingkat kompleksitas intelegensia beragam serta memiliki karakter yang berbeda, maka dari itu penulis menyertakan kelebihan dan kekurangan metode diskusi yang digunakan dalam penelitia ini.

Adapun beberapa kelebihan metode diskusi menurut Sanjaya (2006:156) diantaranya:

1) Diskusi dapat merangsang siswa untuk lebik kreatif khususnya dalam memberikan gagsan dan ide-ide.

2) Dapat melatih siswa untuk membiasakan diri bertukar pikiran dalam mengatasi setiap permasalahan.

3) Dapat melatih siswa utuk dapat mengemukakan pendapat atau gagsan secara verbal. Disamping itu diskusi juga dapat melatih siswa untuk menghargai pendapat orang lain.

Selain kelebihan yang diuraikan oleh sanjaya diatas, ada 
juga beberapa kelebihan yang di sampaikan menurut Adul Azis Wahab (2012: 101)

1) Untuk emecahkan masalah

2) Untuk mengembangkan dan mengubah sikap

3) Untuk menyampaikan dan membantu siswa menyadari adanya pandangan yang berbeda

4) Untuk membantu membangun keterampilan kepemimpinan

5) Untuk memembentu siswa merumuskan masalah dan prinsip-prinsip dan membantunya dalam menggunakan prinsip tersebut

6) Mendorong berfikir logis dan konstruktif

7) Melibatkan siswa dalam belajar menurut kemempuannya dengan menumbuhkan tangung jawabnya untuk belajar dengan meamberi kesempatan untuk menentuakan pendiriannya, mengembangkan

argumentasinya, mempertahankan pandangan pandangannya dengan kemungkinan di kritik oleh anggota kelompoknya
8) Untuk mengembangkan keperacayaan diri, kesadaran dan sikap yang tenang.

Selain beberapa uraian diatas ada beberapa kelebihan menurut A tabrani rusyan (sopidah, 2011:13), menjelskan bahwa kelebihan dari metode diskusi adalah sebagai beriut:

1) Peserta didik memperoleh kesempatan untuk berfikir secara aktif dan kreatif.

2) Peserta didik di harapkan mendapat kesempatan untuk melatih diri dalam mengemukakan pendapat, sikap dan aspirasinya secara bebas, disamping itu ia diatih jiga untuk meghargai pendapat orang lain.

3) Mengebangkan sikap demokratis dikalangan pesrta didik.

4) Menghubungkan atau mendekatkan bahan pelajaran dengan masalah-masalah yang terdapat di masyarakat.

\section{d. Kelemahan Metode Diskusi}

Selain

beberapa

kelebihannya, penulis menyertakan juga kelemahan dari metode diskusi tersebut, yakni 
diantaranya menurut Sanjaya (2006:156):

1) Sering terjadi pembicaraan dalam diskusi oleh 2 orang atau 3 orang siswa yang memiiki keterampilan berbicara.

2) Kadang-kadang pembahasan dalam diskusi meluas, sehingga kesimpulan menjadi kabur.

3) Memerlukan waktu yang panjang, yang kaadang-kadang tidak sesuai dengan yang di rencanakan.

4) Dalam diskusi sering terjadi perbedaan pendapat yang bersifat emosional yang tidak terkontrol. Akibatnya kadangkadang ada pihak yang merasa tersinggung, sehingga dapat mengganggu iklim pembelajaran.

\section{e. Jenis-jenis diskusi}

Agar tidak ada kekeliruan dalam penggunaan metode diskusi pada saat proses pembelajaran berlangsung, sebaiknya kita harus mengetahui jenis-jenis dari metode diskusi tersebut. Lalu, jika kita dengan bebas mengimplementasikannya tanpa mengetahaui jenis-jenisnya, lantas dapatkah kita mencapai pembelajaran yang efektif serta efisien dengan landasan yang terisematis?

$$
\text { Jadi sudah sebuah }
$$

keharusan kita mengetahui jenisjenis metode diskusi agar tidak terjadi kekeliruan sebagaimana dimuka. Secara rinci penulis memaparkan, bahwa terdapat macam-macam diskusi yang dapat digunakan dalam proses pembelajaran.

Adapun Menurut Sanjaya (2006:157) yang menyatakan bahwa jenis-jenis diskusi ada empat macam dantara lain sebagai berikut:

1) Diskusi kelas

Diskusi kelas atau di sebut juga diskusi kelompok adalah proses pemecahan masalah yang di lakukn oleh seluruh anggota kelas sebagai peserta diskusi. prosedur yang di gunakan dalam jenis diskusi ini adalah: pertama, guru membagi tugas sebagai pelaksanaan diskusi,misalnya siapa yang akan menjadi moderator. Kedua, sumber masalah ( guru,siswa, atau ahli tertentu dari luar) memaparkan masalah yang harus di pecahkan 
selama 10-15 menit. Ketiga, siswa diberi kesempatan untuk menanggapi permasalahan setelah mendaptar pada moderator. Keempat, sumber masalah memberi tanggapan. Kelima, moderator menyimpulkan hasil diskusi.

2) Diskusi kelompok kecil

Diskusi kelompok kecil dilakukan dengan membagi siswa dalam kelompok-kelompok. Jumlah anggota kelompok antara lain 3-5 orang. Pelaksanaannya di mulai dengan guru menyajikan permasalahan secara umum, kemudin masalah tersebut dibagibagi ke dalam submasalah yang harus di pecahkan oleh setiap kelompok kecil, selesai diskusi dalam kelompok kecil, ketua kelompok menajikan hasil diskusinya.

3) Simposium

Simposium adalah metode mengajar dengan membahas suatu persoalan di pandang dari berbagai susdut pandang berdasarkan keahlian. Sismposim dilakuakan untuk memberikan wawasan yang luas kepada siswa. Setelah para penyaji memberikan pandangannya tentang masalah yang di bahas, maka simposium diakhiri dengan pembacaan kesimpulan hasil kerja tim perumrus yang telah di tentukan sebelumnya.

4) Diskusi panel

Diskusi panel adalah penambahan suatu masalah yang dilakukan oleh beberpa orang panelis yang bianya terdiri dari 4-5 orang di hadapan audiens. Diskusi panel berbeda dengan diskusi lainya, dalam diskusi panel audiens tidak terlibat secara langsung, tetapi hanya berperan sebagai peninjau para penelis yang sedang melaksanakan diskusi. Oleh sebab itu agar diskusi panel efektif perlu digabungkan dengan motode lain, misalnya dengan metode penugasan. Siswa di suruh untuk nmerumuskan hasil belajar dalam diskusi.

\section{f. Langkah-langkah}

pelaksanaan metode diskusi

Proses pembelajaran yang baik itu selalu memperhatikan prosedur pembelajaran secara umum dan prosedur metode pembelajaran yang akan 
digunakan, agar penggunaan metode diskusi dalam proses pembalajaran IImu Pengetahuan Sosial berhasil dengan efektif, maka harus di lakukan langkah atau persiapan terlebih dahulu.

Adapun menurut Winna sanjaya (2006:158) langkahlangkah yang harus dilakukan dalam melaksanakan metode diskusi antara lain sebagai berikut:

1) Langkah persiapan

Hal-hal yang harus di perhtikan dalam diskusi di antaranya:

a) Merumuskan tujan yang ingin di capai , baik tujuan yang bersifat umum maupun khusus. Tujuan yang ingin di capai mesti dipahami oleh setiap siswa sebagai peserta diskusi. Tujuan yang jelas dapat di dijadikan sebagai kontrol dalam pelaksanaan.

b) Menentukan jenis diskusi yang dapat dilaksanakan sesuai dengan tujuan yang ingin dicapai. Misalnya, apabila tujuan yang ingin dicapai adalah penambahan wawasan siswa tentang suatu persoalan,maka dapat menggunakan diskusi panel, sedangkan jika yang di utamaan adalah engembangkan kemampuan siswa dalam mengembangkan gagsan, maka simposium di anggap sebagai diskusi yang tepat.

c) Menetapkan masalah yang akan di bahas, masalah dapat di tentuan dari isi materi pembelajaran atau masalah masalah aktual yang terjadi di lingkungan masyarakat yang di hubungkan dengan materi pelajaran sesuai dengan bidang studi yang di ajarkan.

d) Mempersiapkan segala sesuatu yang berhubungan dengan teknis pelaksanaan diskusi, misalnya ruang kelas dengan segala fasilitasnya, petugaspetugas diskusi seperti moderator, notulis dan tim perumus.

2) Pelaksanaan Diskusi

$\begin{array}{lr}\begin{array}{l}\text { Beberapa hal yang } \\ \text { dilakukan }\end{array} & \text { dalam } \\ \text { melaksanakan } & \text { diskusi } \\ \text { adalah: } & \end{array}$

a) Memeriksa persiapan yang di anggap dapat mempengaruhi kelancaran diskusi 
b) Memberikan pengarahan sebelum dilaksanakan diskusi, misalnya menyajikan tujuan yang ingin di capai serta aturanaturan diskusi sesui dengan jenis diskusi yang akan di laksanakan

c) Melaksanakan diskusi sesusi dengan aturan main yang telah ditetapkan. Dalam pelaksanaan diskusi hendaknya memperhatikan suasana atau iklim belajar yang enyenagkan, misalnya tidak tegang, tidak saling enyudutkan, dan lain sebagainya.

d) Memberikan kesempatan yang sama kepada setiap peserta diskusi untuk mengeluarkan gagasan atau ide-idenya.

e) Mengendalikan pembicaraan kepada pokok persoalan yang sedang di bahas. Hal ini sangat penting , sebab tanpa pengendalian biasanya arah pembahasan menjadi melebar dan tidak fokus.

3) Menutup Diskusi

Akhir dari proses
pembelajaran
menggunakan diskusi nhendaknya
dilakukan hal-hal sebagai berikut:
a) Membuat
pokok-pokok pembahasan sebagai kesimpulan sesui dengan hasil diskusi.
b) Me-review jalanya diskusi dengan meminta pendapat dari seluruh peserta sebagai umpan balik perbaikan selanjutnya.

\section{Hasil Belajar}

Hasil belajar adalah perubahan prilaku yang berupa pengetahuan atau pemahaman, keterampilan dan sikap yang di peroleh peerta didik selama proses berlangsungnya belajar mengajar atau yang lajim di sebut pembeajaran. Proses penilaian hasil terhadap hasil belajar mempunyai peranan penting dlam proses pembelajaran. Proses penilaian hasil belajar dapat memberikan informasi kepada guru tentang kemajuan peserta didik dalam mencapai tujuantujuan pembelajarannya.

$$
\text { Menurut Susanto ( 2014:1) }
$$
yang mengemukakan bahwa: Hasil belajar secara garis besarnya dibagi menjadi tiga jenis yaitu; 1). Pengetahuan dan pengertian ( kognitif ); 2). Keterampilan dan kebiasaan (Fisikikomotor); 3). 
Sikap dan cita-cita (afektif). Untuk menyatakan bahwa suatu proses belajar mengajar dapat dikatakan berhasil, setiap guru memiliki pandangan masing-masing sejalan dengan pemikirannya. Namun, untuk menyamakan perbedaaan persepsi sebaiknya berpedoman pada kurikulum yang berlaku saat ini. Untuk mengetahui tercapai tidaknya tujuan pembelajaran, pendidik perlu mengadakan tes formatif setiap selesai menyajikan suatu bahasan kepada siswa. Penilaian formatif ini untuk mengetahui sejauhmana peserta didik telah menguasai tujuan pembelajaran yang ingin dicapai. Fungsi penilaian ini adalah untuk memberi umpan balik kepada pendidik dalam rangka memperbaiki proses belajar mengajar dan melaksanakan program ramedial bagi siswa yang belum berhasil.

Horward Kingsley (Sudjana, 2009:22) membagi tiga macam hasil belajar yaitu (a) keterampilan dan kebiasaan,(b) pengetahuan dan pengertian, (c) sikap dan citacita. Masing-masing jenis hasil belajar dapat diisi dengan bahan yang telah ditetapkan dalam kurikulum. Sedangkan Gagne (Sudjana, 2009:22) membagi lima kategori hasil belajar, yaitu (a) informasi verbal, (b) keterampilan intelektual, (c) strategi kognitif, (d) sikap, (e) keterampilan motoris.

Adapun menurut bloom (Sudjana, 2009:22) yang menyatakan bahwa, hasil belajar dibagi menjadi tiga bagian yaitu, ranah kognitif, ranah afektif, dan ranah fisikomotor.

a. Ranah kognitif, berkenaan dengan hasil belajar intelektual yang terdiri dari enam aspek, yakni:

1) Pengetahuan, yaitu berupa pengenalan dan pengingatan kembali terhadap pengetahuan tentang fakta, istilah, dan prinsip-prinsip dalam bentuk seperti mempelajari.

2) Pemehaman, berupa kemampuan memahami tentang isi pelajaran yang dipelejari tanpa perlu menghbungkanya dengan isi pelajaran lain.

3) Aplikasi, merupakan kamampuan menggunakan generalisasi atau abstraksi 
lainya yang sesuai dalam situasi konkrit.

4) Analisis, merupakan kamapuan manjabarkan isi pelajaran ke bagian-bagian yang menjadi unsur pokok.

5) Sintesis, merupakan kemampuan menghubungkan unsur-unsur pokok kedalam struktur yang baru.

6) Evaluasi, merupakan kemampuan menilai isi pelajaran untuk suatu maksud atau tujuan tertentu.

b. Ranah afektif, berkenaan dengan sikap yang terdiri dari lima aspek yakni:.

1) Menerima, berupa perhatian terhadap stimulasi secara pasif yang meningkat secara lebih aktif.

2) Merespon, merupakan kesempatan untk menanggapi stimulan dan mereasa terikat serta secara aktif memperhatikan.

3) Menilai, merupakan kemampuan menilai gejala atau kegiatan sehingga dengan sengaja merespon lebih anjut untuk mencari jalan bagaimana dapat mengambil bagian atas terhadap apa yang terjadi.

4) Mengorganisasi, merupakan kemampuan untuk membentuk suatu sistem nilai bagi dirinya berdasarkan nilai-nilai yang dipercaya.

5) Karakterisasi, merupakan kemampuan untuk mengkonseptualisasikan masing-masing nilai pada waktu merespon dengan jalan mengidentifikasi karakterisktik nilai atau mebuat pertimanganpertimbangan.

c. Ranah psikomotor ,berkenaan dengan hasil belajar keerampilan da kemempuan bertindak, ada enam aspek ranah psikomotoris yakni;

1) Gerakan reflek, keterampilan gerakan yang tidak sadar

2) Keterampilan pada gerakangerakan sadar

3) Kemampuan perseptual, termasuk di dalamnya membedakan visual, membedakan auditif motoris, dll.

4) Kemampuan di bidang fisik, misalnya kekutan, keharmonisan, dan ketepatan. 
5) Gerakan-gerakan skill, mulai dari keterampilan sederhana sampai pada keterampilan yang kompleks

6) Keterampilan yang berkenn dengan komunikasi nondecursive seperti gerakan ekspresif da interpretatif.

Carl Rogers (Sagala, 2009:31) berpendapat bahwa seseorang yang telah menguasai tingkat kognitif perilakunya sudah bisa diramalkan. Dalam proses belajar-mengajar disekolah saat ini, tipe hasil belajar kognitif lebih dominan jika dibandingkan dengan tipe hasil belajar bidang afektif dan psikomotoris. Sekalipun demikian tidak berarti bidang afektif dan psikomotoris diabaikan sehingga tak perlu dilakukan penelitian. Tipe hasil belajar ranah afektif dengan perasaan, minat dan perhatian, keinginan, penghargaan. Manakala seseorang dihadapkan kepada objek tertentu. Misalnya bagaimana sikap siswa pada waktu belajar disekolah,terutama pada waktu guru mengajar. Sikap tersebut dapat dilihat dalam hal:

1) Kemauannya untuk menerima pelajaran dari guru.
2) Perhatiannya terhadap apa yang dijelaskan oleh guru.

3) Keinginannya untuk mendengarkan dan mencatat uraian guru.

4) Penghargaannya terhadap guru itu sendiri.

5) Hasratnya untuk bertannya kepada guru.

Sedangkan sikap siswa setelah pelajaran selesai dapat dilihat dalam hal:

1) Kemauannya mempelajari bahan pelajaran lebih lanjut.

2) Kemauannya untuk menerapkan hasil pelajaran dalam praktek kehidupannya sesuai dengan tujuan isi yang terdapatdalam mata pelajaran.

3) Senang terhadap guru dan mata pelajaran yang diberikannya.

Kondisi dan karakteristik siswa diatas merupakan cirri-ciri dari hasil belajar ranah afektif. Tipe hasil belajar ranah psikomotoris berkenan dengan keterampilan atau kemampuan bertindak setelah ia menerima pengalaman belajar tertentu. Hasil belajar ini sebenarnya tahap lanjutan dari hasil belajar afektif yang baru tampak dalam kecendrungan- 
kecendrungan untuk berprilaku. Contoh-contoh hasil belajar ranah afektif diatas dapat menjadi hasil belajar psikomotoris manakala siswa menunjukan prilaku atau perbuatan tertentu sesuai dengan makna yang terkandung didalam ranah afektifnya sehingga kedua ranah tersebut jika dilukiskan akan tampak sebagai berikut.

Hasil Belajar Afektif dan Hasil Belajar Psikomotoris menurut Sudjana (2009:32), yaitu : kemauan untuk menerima pelajaran dari guru, perhatian siswa terhadap apa yang dijelaskan oleh guru, penghargaan siswa terhadap guru, hasrat untuk bertannya terhadap guru, kemampuan untuk mempelajari bahan pelajaran lebih lanjut, kemauan untuk menerapkan hasil belajar, dan senang terhadap guru dan mata pelajaran yang telah diberikannya, sedangkan hasil belajar psikomotor, yaitu : segera memasuki kelas pada waktu guru datang danduduki paling depan mempersiapkan kebutuhan belajar, mencatat bahan pelajaran dengan baik dan sistematis, sopan, ramah, dan hormat kepada guru pada saat guru menjelaskan pelajaran, mengangkat tangan dan bertanya kepada guru mengenai bahan pelajaran yang belum jelas, keperpustakaan untuk belajar lebih lanjut atau meminta informasi kepada guru tentang buku yang harus dipelajari, atau segera untuk membentuk kelompok untuk berdiskusi, melakukan latihan diri dalam memecahkan masalahberdasarkan konsep bahan yang telah diperolehnya atau menggunakannya dalam praktek kehidupannya, dan akrab dan mau bergaul, mau berkomunikasi dengan guru, dan bertanya atau meminta saran bagaimana mempelajari mata pelajaran yang diajarkannya.

Ketiga ranah tersebut menjadi objek penilaian hasil belajar. Di antara ketiga ranah itu, ranah kognitiflah yang paling banyak dinilai oleh para pendidik di sekolah karena berkaitan dengan kemampuan para peserta didik dalam menguasai isi bahan pengajaran. Belajar adalah kegiatan yang dilakukan oleh peserta didik dalam proses pembelajaran atau proses mental 
yang terjadi dalam diri seseorang, sehingga menyebabkan munculnya perubahan perilaku.

Belajar adalah proses perubahan tingkah laku. Namun demikian, kita akan sulit melihat bagaimana proses terjadinya perubahan tingkah laku dalam diri seseorang, oleh karena itu perubahan tingkah laku berhubungan dengan perubahan sistem syaraf dan perubahan energi yang sulit dilihat dan diraba. Oleh sebab itu, terjadinya proses perubahan tingkah laku merupakan suatu misteri, atau para ahli psikologi menamakannya sebagai kotak hitam (black box) (Sanjaya, 2009:228).

Walaupun kita tidak dapat melihat proses terjadinya perubahan tingkah laku pada diri setiap orang, tetapi sebenarnya kita bisa menentukan apakah seseorang telah belajar atau belum, yaitu dengan membandingkan kondisi sebelum dan sesudah proses pembelajaran berlangsung.

Dari beberapa pendapat tentang hasil belajar diatas maka dapat disimpulkan bahwa hasil belajar adalah hasil yang diperoleh peserta didik setelah mengalami interaksi proses pembelajaran melalui evaluasi belajar IPS yang dilakukan dengan tes yang dijadwalkan kemajuan yang diperoleh peserta didik tidak hanya berupa ilmu pengetahuan, tetapi juga berupa sikap dan kecakapan atau keterampilan khususya dalam pembelajaran IPS.

Dari kedua pernyataan tersebut peneliti dapat menyimpulkan bahwa: hasil belajar adalah kemampuan-kemempuan yang dimiliki oleh siswa setelah ia menerima pengalaman belajarnya. Hasil belajar menjadi objek penilaian pada hakikatnya menilai penguasaan peserta didik terhadap tujuan-tujuan instuksional, hal ini adalah karena isi dari rumusan intruksional menggambarkan hasil belajar yang harus di kuasai siswa setelah meneriama atau menyelasaikan pengalaman belajarnya. Hasil belajar sebagai objek penilian dapat dibedakan menjadi beberapa katagori, antara lain keerampilan dan kebiasaan, pengetahuan dan pengertian, 
sikap dan cita-cita. Katagori yang banyak di gunakan dibagi menjadi tiga ranah, yakini kognitif, afektif, dan fisikomotoris. Dari ketiga ranah tersebut masing-masing terdiri dari sejumlah aspek yang saling bekaitan dan alat penilaian untuk setiap ranah tersebut mempunyai karakteristik tersendiri sebab setiap ranah berbeda dalam cangkupan dan hakikat yang terkandung di dalamnya.

\section{METODE PENELITIAN}

Metode penelitian merupakan cara yang dipakai dalam mengumpulkan data. Suatu penelitian akan memperoleh data yang tepat dan sesuai dengan masalah yang dipakai, apabila ditopang oleh metode penelitian yang tepat. Banyak metode yang dapat dipergunakan guna mencapai hasil penelitian yang baik. Menurut Ruseffendi (Margaretha,2008:4) Penelitian kelas merupakan suatu tindakan yang terarah, terencana, cermat, dan penuh perhatian yang dilakukan oleh praktisi pendidikan (guru) terhadap permasalahan yang ada dalam kelas yang bertujuan untuk perbaikan pendidikan seperti metode mengajar, kurikulum dan lain sebagainya.

Dilihat dari segi pendekatan metodeologinya, penelitian ini merupakan Penelitian Tindakan Kelas (PTK) denga titik fokus yang dilakukan guru atau sekelompok guru untuk menguji anggapananggapan dari suatu teori pendidikan daam praktik, atau sebagai arti dari evalusi dan melaksanakan seluruh prioritas program sekolah. David Hopskin (Margaretha,2008:4). Dalam hal ini suatu bentuk kajian yang bersifat reflektif, yang dilakukan oleh pelaku tindakan untuk meningkatkan kemantapan rasional dari tindakan-tindakannya dalam melaksanakan tugas dan memperdalam pemahaman terhadap kondisi dalam praktik pembelajaran.Hopkins

(Muslich,2009:8).

Menurut hemat penulis penelitian Tindakan kelas adalah sebuah bentuk penelitian yang merefleksikan dengan melakukan beberapa tindakan terterntu namun tersistematis guna memcahkan 
masalah dan meningatkan praktik pembelajaran yang baik.

Disamping itu ada pendapat yang sejalan dengan penulis yakni diantaranya,

Suyanto

(Muslich,2009:9) mengemukakan bahwa PTK adalah suatu bentuk penelitian yang bersifat reflektif dengan melakukan tindakantindakan tertentu agar dapat memperbaikidan/atau

meningkatkan praktik-praktik pembelajaran dikelas secara profesional.

Sadikin dalam (Dayana, 2011:58) mengemukakan bahwa : Penelitian tindakan kelas adalah suatu bentuk penelitian yang dialaksankan oleh guru untuk memcahkan masalah yang dihadapi dalam melaksanakan tugas pokoknya, yaitu mengelola pelaksanaan kegiatan. PTK merupakan kolaboratif suatu pendekatan pembelajaran untuk meningkatkan kualitas pendidikan khusunya didalam kelas.

Arikunto

dalam

(Dayana,2011:58) menyatakan bahwa : Penelitian tindakan kelas yaitu penelitian yang dilakukan oleh guru, bekerja sama dengan peneliti (atau dilakukan oleh guru sendiri yang juga bertindak sebagai peneliti) dikelas atau disekolah tempat ia mengajar dengan penekanan pada penyempuranaan atau peningkatan proses dan praktis pembelajaran.

Ada beberapa tujuan PTK menurut Margaretha 2008:10 adalah untuk memecahkan permaslahan yang terjadi di kelas dan meningkatkan kegiatan guru dalam pengembangan profesionalnya. Secara rinci, tujuan PTK antara lain :

1. Meningkatkan kualitas isi, masukkan, proses, dan hasil pendidikan dan pembelajaran di sekolah.

2. Membantu guru dan tenaga kependidikan lainnya mengatasi masalah pembelajaran.

3. Hasil penelitian dapat mendukung langsung pembelajaran yang sedang berlangsung.

4. Meningkatkan sikap profesional pendidik dan tenaga kependidikan, serta

5. Menumbuhkembangkan budaya akademik di lingkungan sekolah 
sehingga tercipta sikap proaktif dalam melakukan perbaikan kualitas pendidikan dan pembelajaran secara

berkelanjutan.

Melaksanakan PTK memberi banyak manfaat bagi guru, siswa, sekolah, maupun kepentingan pendidikan pada umumnya sebagaimana yang disebutkan oleh Margaretha( 2008:14) yaitu :

1. Dapat menghasilkan laporanlaporan PTK yang dapat dijadikan bahan panduan guru untuk meningkatkan mutu pembelajaran. Selain itu, hasilhasil PTK yang dilaporkan dapat menjadi bahan artikel ilmiah atau makalah untuk berbagai kepentingan, antara lain disajikan dalam forum ilmiah dan dimuat dalam jurnal ilmiah.

2. Menumbuhkembangkan kebiasaan, budaya, dan tradisi meneiti serta menulis artikel ilmiah di kalangan guru. Hal ini telah ikut mendukung profesionalisme dan karir guru.

3. Mempu mewujudkan kerja sama, kolaborasi, dan sinergi antar guru dalam satu sekolah atau beberapa sekolah untuk bersama-sama memecahkan masalah pembelajaran dan meningkatkan mutu pembelajaran.

4. Mampu meningkatkan kemampuan guru dalam menjabarkan kurikulum atau program pembelajaran sesuai dengan tuntutan dan konteks lokal, sekolah, dan kelas. Hal ini memperkuat relevansi pembelajaran bagi kebutuhan siswa.

5. Dapat memupuk dan meningkatkan keterlibatan, kegairahan, ketertarikan, kenyamanan dan kesenangan siswa dalam mengikuti proses pembelajaran di kelas yang dilaksanakan guru. Hasil belajar siswa pun dapat meningkat.

Dapat

mendorong terwujudnya proses pembelajaran yang menarik, menantang, nayaman dan menyenangkan karena strategi, metode, teknik dan media yang digunakan bervariasi dan dipilih secara sungguhsungguh.

\section{HASIL DAN PEMBAHASAN}


1. Peningkatan Hasil Belajar IPS Melalui Metode Diskusi

Hasil penelitian menunjukkan bahwa pada kondisi awal baru $19 \%$ siswa yang mencapai KKM. Berangkat dari temuan tersebut peneliti berusaha meningkatkan hasil belajar IPS menggunakan metode diskusi. Pada siklus I terjadi peningkatan sebesar $44 \%$ dari $19 \%$ menjadi $63 \%$. Hal ini membuktikan bahwa tindakan pada siklus I memiliki pengaruh terhadap hasil belajar IPS siswa. Akan tetapi, peningkatan tersebut belum dikatakan berhasil. Hal ini dikarenakan presentase siswa yang mencapan KKM belum mencapai $\geq 70 \%$. Selain itu, hasil refleksi menunjukkan bahwa pelaksanaan tindakan siklus I masih dirasa kurang optimal dan belum sesuai dengan hasil yang diharapkan. Meskipun sudah berjalan sesuai perencanaan awal, tetapi masih ada kekurangan yang perlu diperbaiki, yakni: Ada beberapa siswa yang belum memahami tahapan-tahapan diskusi, siswa kurang terbuka dan mengkomunikasikan dengan guru apabila menemui kesulitan, siswa mengalami kesulitan dalam diskusi nampaknya Sering terjadi pembicaraan dalam diskusi oleh 2 orang atau 3 orang siswa, selanjutnya kadang-kadang dalam diskusi sering terjadi perbedaan pendapat siswa yang bersifat emosiaonal yang tidak terkontrol dan akibatnya siwa kadangkadang ada ang tersinggung sehingga dapat mengganggu iklim pembelajaran diskusi dan selanjutnya ketika pembahasan dalam diskusi meluas, sehingga kesipulan menjadi kabur tidak efektif dan kondusif serta siswa juga masih memerlukan waktu yang panjang saat diskusi yang kadang kadang tidak sesui dengan apa yang guru rencanakan.

\section{Kekurangan}

tersebut diperbaiki pada siklus II dengan menciptakan suasana pembelajaran yang lebih santai, menyenengkan namun terkendali . Ditahapan siklus ke II yang tadinya belum memhami tahapan-tahapan diskusi sekarang sudah nampak memahaminya. Yang tadinya siswa kurang terbuka dan mengkomunikasikan dengan guru apabila menemui kesulitan, 
sekarang sudah mulai terbuka dan berani menanyakannya, di dalam siklus I kesulitan dalam diskusi nampaknya Sering terjadi pembicaraan dalam diskusi oleh 2 orang atau 3 orang siswa, tetapi di siklus II siswa sudah mulai terkontrol dan diskusi bisa di kendalikan dengan lancar. Selanjutnya di siklus I kadangkadang dalam diskusi sering terjadi perbedaan pendapat yang bersifat emosiaonal yang tidak terkontrol dan akibatnya siwa kadangkadang ada yang tersinggung sehingga dapat mengganggu iklim pembelajaran diskusi namun di siklus II siswa nampak lebih bisa menggahrgai satu sama lainnya jadi iklim diskusi bisa dikatakan lancar dan selanjutnya di siklus II pembahasan diskusi lebih mengerucut dan tidakk meluas, sehingga kesipulan menjadi lebih efektif dan optimal.

Berdasarkan

hasil pengamatan pada siklus II menunjukkan bahwa hasil belajar IPS siswa mengalami peningkatan. Pada siklus I terjadi peningkatan sebesar 44\% dari 19\% menjadi $63 \%$. Pada siklus II mengalami peningkatan sebesar 30\% yakni dari $63 \%$ menjadi 93\%. Peningkatan hasil belajar siswa dari pratindakan sampai siklus II dapat diakumulasikan sebesar $70 \%$.

Berdasarkan

hasil pengamatan pada siklus II juga menunjukkan bahwa suasana pembelajaran lebih efektif dan optimal. Sebagian besar siswa mulai aktif baik dalam proses pembelajaran maupun dalam diskusi. Siswa juga lebih percaya diri berbaur dengan lawan jenis. Siswa juga nampak berantusias dan berekspresi dalam berdiskusi. Siswa juga lebih cepat memahami materi pembelajaran. Dengan demikian, pembelajaran IPS dengan menggunakan metode diskusi ini dapat menciptakan kegiatan pembelajaran yang lebih aktif dan kondusif. Hal tersebut selaras dengan pendapat Abdul azis wahab (2012:100) bahwa diskusi merupakan metode yang sangat berguna dalam pembelajaran IPS, karna metode diskusi merupakan metode yang paling sulit sekaligus paling mujarab dan ampuh maka dari itu 
penerapanmetode diskusi harus di terapkan sejak dini.

Adapun metode diskusi menrut winna sanjaya (2008:152) mengemukakan bahwa metode diskusi adalah metode pembelajaran yang mengharapkan siswa untuk memecahkan masalah , menambah pengetahuan, dan menjwab pertanyaan. Sejalan degan pendapat pendapat atas adapun manfaat diskusi menurut Sagala (2014:208) adalah sebagai berikut:

a. Peserta didik memperoleh kesempatan untuk berfikir

b. Peserta didik mendapat pelatihan mengeluarkan pendaapat, sikap dan aspirasinya secara bebas

c. Peserta didik belajar bersikap toleran terhadap temantemannya

d. Diskusi dapat menumbuhkan partisipasi aktif dikalangan peserta didik

e. Diskusi dapat mengembangkan sikap demokratif, dapat menghargai pendapat orang lain dan; f. Dengan diskusi, pelajaran menjadi relevan dengan kebutuhan masyasrakat.

2. Proses Pembelajaran IPS Melalui Metode Diskusi

Berdasarkan hasil observasi aspek afektif siswa selama proses pembelajaran IPS menggunakan metode diskusi mengalami peningkatan. Pada siklus I, siswa yang mendapatkan nilai antara 16 sampai 20 adalah 7 siswa dari 27 siswa, jika dipersentase 26\%, sedangkan pada siklus II meningkat menjadi 10 siswa dari 27 siswa, jika dipersentase 37 dengan keterangan sangat baik. Siswa yang mendapatkan nilai antara 11 sampai 15 pada siklus I adalah 17 siswa dari 27 siswa, jika dipersentase $63 \%$, pada siklus II ada 15 siswa dari 27 siswa, jika dipersentase $56 \%$ dan Siswa yang mendapatkan nilai antara 6 sampai 10 hanya ada pada siklus I yaitu 3 siswa dari 27 siswa, jika dipersentase $11 \%$ dengan keterangan kurang, sedangkan pada siklus II ada 2 sswa dari 27 siswa, jika di presentase $7 \%$. Sedangkan pada siklus I maupun 
siklus II tidak ada siswa yang mendapat nilai kurang dari 5 .

Berdasarkan hasil observasi aspek psikomotor siswa selama proses pembelajaran IPS menggunakan metode diskusi mengalami peningkatan. Pada siklus I, siswa yang mendapatkan nilai antara 16 sampai 20 adalah 6 siswa dari 27 siswa, jika dipersentase $22 \%$, sedangkan pada siklus II meningkat menjadi 8 siswa dari 27 siswa, jika dipersentase $30 \%$ dengan keterangan sangat baik. Siswa yang mendapatkan nilai antara 11 sampai 15 pada siklus I adalah 18 siswa dari 27 siswa, jika dipersentase $67 \%$, pada siklus II adalah 17 siswa dari 27 siswa, jika dipersentase $63 \%$ dengan keterangan baik. Siswa yang mendapatkan nilai antara 6 sampai 10 hanya ada pada siklus I yaitu 3 siswa dari 27 siswa, jika dipersentase $11 \%$ dengan keterangan kurang, sedangkan pada siklus II ada 2 siswa dari 27siswa, jika dipresentase 7\%. Pada siklus I maupun siklus II tidak ada siswa yang mendapat nilai kurang dari 5 .
Berdasarkan hasil observasi aktivitas guru selama proses pembelajaran IPS menggunakan metode diskusi mengalami peningkatan. Pada siklus I, jumlah skor observasi guru yaitu sebesar 41 yang termasuk pada kategori baik. Sedangkan Pada siklus II diketahui bahwa jumlah skor observasi guru yaitu sebesar 56 yang termasuk pada kategori sangat baik.

Hasil pengamatan dari siklus I ke siklus II menunjukkan bahwa pelaksanaan pembelajaran dengan menggunakan metode diskusi dalam pembelajaran IPS menunjukkan peningkatan dan perbaikan. Hal ini dirasa cukup memuaskan bagi guru dan peneliti, karena indikator keberhasilan sudah tercapai.

Hasil belajar IPS yang siswa peroleh dirasa cukup memuaskan bagi guru dan peneliti, karena indikator keberhasilan sudah tercapai yaitu 25 siswa telah mencapai KKM atau 93\% dari jumlah keseluruhan siswa. Berdasarkan hasil yang diperoleh dari tahap pratindakan sampai dengan tindakan siklus II, dapat 
disimpulkan bahwa penerapan metode diskusi memberikan dampak positif, karena penerapan metode diskusi dinilai berhasil dan dapat meningkatkan hasil belajar IPS siswa.

Berdasarkan uraian di atas, maka untuk melaksanakan metode diskusi dalam pembelajaran IPS perlu memperhatikan : (1) Agar siswa tidak kesulitan dalam melakukan diskusi, maka perlu diberikan pengarahan dari sebelum melakukan diskusi, (2) Agar siswa lebih fokus dalam mengobservasi dan tidak ramai sendiri, maka perlu diberikan kesibukan dengan mengerjakan Lembar Kerja Siswa; (3) Agar waktu pembelajaran IPS lebih efisien dan efektif, maka perlu melaksanakan langkah-langkah metode diskusi secara utuh/keseluruhan pada satu pertemuan saja (2x35 menit); (4) Agar siswa lebih percaya diri dan komunikatif dengan guru maupun peneliti, maka perlu menciptakan suasana pembelajaran yang santai, menyenangkan namun terkendali yaitu dengan lebih banyak mengajak siswa berdiskusi.

\section{Keterbatasan Hasil Penelitian}

Penelitian yang dilakukan di kelas V SDN Sukabakti dalam pelaksanaannya masih terdapat kekurangan, keterbatasan serta hambatan.

Kekurangan, keterbatasan dan hambatan tersebut, seperti berikut :

a. Partisipasi siswa tidak terlalu maksimal dikarnakan tidak semua siswa aktif ketika proses pembelajaran menggunakan metode diskusi berlangsung.

b. Pelaksanaan penelitian terbatas karna akan menghadapi UTS.

\section{E. KESIMPULAN}

\section{Peningkatan Hasil Belajar IPS Siswa}

Berdasarkan hasil analisis data atas penelitian yang telah dilakukan, maka dapat disimpulkan bahwa penerapana metode diskusi dapat meningkatkan hasil belajar siswa Kelas V SDN Sukabakti. Hasil tersebut berdasarkan data awal sebelum adanya tindakan diperoleh hasil dengan rata-rata pra siklus siswa yaitu $51,55 \%$ dengan nilai tertinggi yaitu 70 dan 
nilai terendah 20 dengan ketuntasan sebesar $19 \%$ dan ketidak tuntasan $81 \%$. Sedangkan pada siklus I diperoleh hasil dengan rata-rata kelas yaitu 65,18 dengan nilai tertinggi yaitu 80 dan nilai terendah 40 dengan ketuntasan sebesar $63 \% \%$ dan ketidaktuntasan 37\%. Siklus II diperoleh hasil dengan rata-rata kelas yaitu 82,59 dengan nilai tertinggi 100 dan nilai terendah 60 dengan ketuntasan sebesar $93 \%$ dan ketidak tuntasan sebesar $7 \%$. Hal tersebut menunjukan bahwa hasil belajajar IPS mengalami peningkatan secara signifikan. Pada siklus I terjadi peningkatan sebesar 44\% dari 19\% menjadi $63 \%$, pada siklus II mengalami peningkatan sebesar sebesar $30 \%$ yakni dari $63 \%$ menjadi $93 \%$, pada pra siklus hanya 5 siswa dari 27 siswa atau $19 \%$ siswa yang memenuhi KKM.

Pada siklus I meningkat menjadi 17 atau $63 \%$ dan pada siklus II meningkat menjadi 25 siswa yang memenihi KKM atau sebesar $93 \%$ dari jumlah seluruh siswa. Berdasarkan hasil yang diperoleh dari tahap pra siklus sampai dengan tindakan siklus II, dapat disimpulkan bahwa penerapan metode diskusi memberikan dampak positif, karena penggunaan metode diskusi dinilai berhasil dan dapat meningkatkan hasil belajar IPS siswa. Berdasarkan hasil penelitian dan pembahasan dalam penelitian tindakan kelas, maka dapat disimpulkan bahwa metode diskusi dapat meningkatkan hasil belajar IPS siswa kelas V SDN Sukabakti.

Apabila melihat proses yang terjadi pada saat pembelajaran IPS setelah menggunakan metode diskusi pada siklus I mengalami perubahan yang baik. Tetapi pada proses pembelajaran siklus I, masih terdapat beberapa siswa yang kurang antusias dalam mengikuti pembelajaran atau bisa dikatan pasif dan menunjukkan perilaku negatif lainnya dalam mengikuti pembelajaran. Hal tersebut bisa diliahat dari sikap siswa yaitu 7 siswa atau $26 \%$ siswa biasa dikatagorikan sangat baik dalam mengikuti pembelajaran, 17 siswa atau $63 \%$ siswa bisa diktagorikan baik sedangkan masih ada 3 siswa 
atau $11 \%$ yang belum bisa mengikuti pembelajaran diskusi dengan baik atau bisa dikatakan kurang baik. Kemudian pada siklus II mengalami peningkatan 30\% atau bisa dikatakan hampir seluluh siswa dari 27 siswa menunjukan sikap yang baik dan sangat baik, namun hanya 2 diantra 27 siswa yang masih kurang baik dalam mengikuti pembelajaran dikarenakan butuh bimbingan khusus untuk menghadapinya. Berdasarkan pemaparan diatas maka dapat di simpulkan bahwa proses

pembelajaran menggunakan metode diskusi secara keseluhan siswa sudah bisa mengikuti pembelajaran dengan baik, aktif dan kondusif.

\section{Peningkatan}

Proses

\section{Pembelajaran Siswa Dengan Metode Diskusi}

Berdasarkan hasil penelitian dan pembahasan dalam penelitian tindakan kelas, maka dapat disimpulkan bahwa metode diskusi dapat meningkatkan hasil belajar IPS siswa kelas V SDN Sukabakti. Apabila melihat proses yang terjadi pada saat pembelajaran IPS setelah menggunakan metode diskusi pada siklus I mengalami perubahan yang baik. Tetapi pada proses pembelajaran siklus I, masih terdapat beberapa siswa yang kurang antusias dalam mengikuti pembelajaran atau bisa dikatan pasif dan menunjukkan perilaku negatif lainnya dalam mengikuti pembelajaran. Hal tersebut bisa diliahat dari sikap siswa yaitu 7 siswa atau $26 \%$ siswa biasa dikatagorikan sangat baik dalam mengikuti pembelajaran, 17 siswa atau 63\% siswa bisa diktagorikan baik sedangkan masih ada 3 siswa atau $11 \%$ yang belum bisa mengikuti pembelajaran diskusi dengan baik atau bisa dikatakan kurang baik. Kemudian pada siklus II mengalami peningkatan 30\% atau bisa dikatakan hampir seluluh siswa dari 27 siswa menunjukan sikap yang baik dan sangat baik, namun hanya 2 diantra 27 siswa yang masih kurang baik dalam mengikuti pembelajaran dikarenakan butuh bimbingan khusus untuk menghadapinya. Berdasarkan pemaparan diatas maka dapat di simpulkan bahwa proses pembelajaran 
menggunakan metode diskusi secara keseluhan siswa sudah bisa mengikuti pembelajaran dengan baik, aktif dan kondusif.

\section{DAFTAR PUSTAKA}

Arif, Baehaki Dikdik. (2009 27 Desember).

https://baehaqiarif.files.wordpr ess.com/2009/12/sejarah.pdf [29 Agustus 2015]

Arikunto, Suharmi dkk. (2014). Penelitian Tindakan Kelas. Jakarta: Bumi Aksara

Arikunto, Suharsimi. (2002).

Prosedur Penelitian: Suatu Pendekatan Praktek. Edisi Revisi V. Jakarta: Rineka Cipta.

Dayana, Rikrik

Meningkatkan Pemahaman Konsep Dan Kemampuan Berfikir Kritis Siswa Sd Pada Mata Pelajaran Ips Melalui Strategi React : Penelitian

Tindakan Kelas Pada Siswa Kelas IV SDN Tikukur 4 Bandung. S2 thesis, Universitas Pendidikan Indonesia.

Hamalik, Oemar. (1993). Pengembangan Kurikulum dan
Pembelajaran.

Bandung:

Trigenda Karya.

Hamdayama, Jumanta. (2014).Model dan Metode Pembelajran kreatif dan berkarakter. Bogor: Ghalia Indonesi.

Hendayani, Heni (2014).

Penerapan Metode disusi

Untuk Meningkatkan Hasil Belajar Siswa Dalam pembelajaran IPA tentang Sumber Daya Alam. UPI Bandung: Tidak di terbitkan. Ismaun. (1993) Modul IImu Pengetahuan Sosisal 9: Pengantar IImu Sejarah. Universitas Terbuka: Jakarta. Koniman, Nana. (2013). Penerapan Metode Diskusi Pada Pembelajaran IPS Materi Perkembangan Teknologi Untuk Meningkatkan Hasil Belajar Siswa. UPI: Tidak di Terbitkan.

Natalia, Margaretha. (2008). Penelitian Tindakan Kelas. Bandung: Tinta Emas fublising. Oemar Hamalik. (2001). Proses Belajar Mengajar. Jakarta: Bumi Aksara. 
Prestiana. (2013). Upaya

Meningkatkan Hasil Belajar Ips Menggunakan Metode Role Playing Pada Siswa Kelas Va Sd Negeri Panjatan Kabupaten Kulon Progo. Skripsi sarjana UNY Yogyakarta.

Purwanto. (2008). Evaluasi Hasil

Belajar. Surakarta: Pustaka Pelajar.

Sagala , Syaiful. (2014). Konsep

dan Makna Pembelajaran.

Bandung: Alfabeta.

Sanjaya, Winna.(2006). Setrategi

Pembelajaran berorientasi

Stndar Proses Pendidikan.

Jakarta: Kencana.

Sapriya. (2014). Pendidikan IPS

konsep dan pembelajaran.

Bandung:

Remaja

Rosdakarya.

Sjamsuddin, Helius (1996)

Metodologi Sejarah, Jakarta:

Depdikbud, Proyek

Slameto. (2003). Belajara dan

Faktor-faktor yang

Mempengaruhinya. Jakarta: PT

Rineka Cipta.

Sopidah. (2011). Penerapan

Metode Diskusi Untuk

Meningkatkan Hasil Belajar

Siswa Dalam Pembelajaran
IPS di Kelas IV Sekolah Dasar.

UPI Bandung: Tidak di Terbitkan.

Sudjana, Nana (2005). Dasardasar Proses Belajar Mengajar. Bandung: Sinar Baru Algensindo.

Sudjana, Nana. (2009). Penilain

Hasil Proses Belajar Mengajar.

Bandung: Remaja rosdakarya.

Sumantri, Mulyani. (1999). Strategi

Belajar Mengajar. Jawa

Tengah:

DepartemenPendidikan dan Kebudayaan.

Suparwoto. (2004). Kemampuan

Dasar Mengajar. Yogyakarta::

FIP Universitas Negri

Yogyakarta.

Susanto, A. (2013). Pembelajaran

Di Sekolah Dasar. Jakarta:

Pranadamedia Grup

Sussanto, A.

(2014).

Penngembangan

Pembelajaran IPS di Sekolah

Dasar. Jakarta: Pranadamedia Grup

Wahab, Abdul Azis.(2012). Metode da Model-Model Mengajar IImu penegtahuan sosial IPS.

Bandung: Alfabeta. 